\title{
Kosovo's Constitutionalism and Some Notes on the Legitimacy of the Spanish Position
}

\section{El constitucionalismo kosovar y algunos apuntes acerca de la legitimidad de la posición de España}

Le constitutionnalisme du Kosovo et certaines remarques sur la légitimité de la position espagnole

\section{Ana M. Jara Gómez*}

Summary: I. Introduction. II. The Grundnorm of the Kosovar Legal System. III. Recognition of States and the Contravention of Ius Cogens Rules. IV. Kosovo from Spain:The Perversion of a Biased Gaze. V. Final Remarks. VI. Bibliography.

* Universidad de Jaén, Spain; ORCID ID: https: //orcid.org/0000-0002-7565-0214, ajar a6@ugr.es. 
RESUMEN: Este artículo se acerca a la última parte del itinerario seguido por Kosovo en la determinación final de su estatus, que será descrita con base en los documentos y actuaciones de las partes implicadas y en el papel jugado por la comunidad internacional. Estos aspectos son de la mayor relevancia para averiguar si existe la posibilidad de que una Constitución sea la norma suprema de un determinado sistema jurídico, dotando de validez a las normas que lo componen y a la vez se subordine a otro acto jurídico diferente. El artículo analiza el Plan Ahtisaari y la Constitución de Kosovo a la luz del concepto kelseniano de norma fundante básica. Se examinará también, en términos de legitimidad y eficacia, cuáles son las consecuencias de la revitalización de las viejas pulsiones nacionalistas en España, que están afectando directamente al presente de Kosovo.

Palabras clave: Kosovo, Constitución, Declaración de Independencia, norma fundante básica, Grundnorm, Plan Ahtisaari.

ABSTRACT: This article is an approach to the last piece of the itinerary followed by Kosovo in the determination of its status, that will be described focusing on the documents and actions of the parties concerned and on the role played by the international community. The relevance will prove when it comes to figure whether there is a possibility that a Constitution is the superior legal act of a given system, providing validity to the rules of such system, while at the same time subordinating itself to another act with legal meaning. The article analyses the Ahtisaari Plan and the Constitution of Kosovo, looking at them in the light of the kelsenian concept of the basic norm. It will be examined, in terms of legitimacy and effectiveness, what are the consequences of the revitalization of old nationalist drives in Spain, which are impacting directly on Kosovo's present.

Key words: Kosovo, Constitution, Declaration of Independence, basic norm, Grundnorm, Ahtisaari Plan.

RÉSUMÉ: Cet article est une approche du dernier morceau de l'itinéraire suivi par le Kosovo dans la détermination de son statut, qui sera décrit en se focalisant sur les documents et les actions des parties concernées et sur le rôle joué par la communauté internationale. La signification de cet article sera mise en évidence lorsqu'il s'agira de déterminer s'il est possible qu'une Constitution soit l'acte juridique supérieur d'un système donné, conférant une validité aux règles de ce système, tout en se subordonnant à un autre acte ayant une signification juridique. L'article analyse le Plan Ahtisaari et la Constitution du Kosovo, en les examinant à la lumière du concept kelsenien de la norme fondamentale. Il sera examiné, en termes de légitimité et d'efficacité, quelles sont les conséquences de la revitalisation des anciennes pulsions nationalistes en Espagne, qui ont un impact direct sur le présent du Kosovo.

Mots-clés: Kosovo, Constitution, Déclaration d'indépendance, norme fondamentale, Grundnorm, Plan Ahtisaari. 


\section{INTRODUCTION}

The question of sovereignty, though constantly evolving, has an enormous relevance both in the legal and the academic fields, and in the world of the Realpolitik. In the case of Kosovo, it is possible to conclude that sovereignty turned temporarily irrelevant given that at least between 1999 and 2008 there was no state that could in fact neither exercise it nor assert the competences and attributes attached to it. After the military intervention of NATO in 1998, United Nations deployed a territorial administration in Kosovo which placed all the attributes of sovereignty and the instruments of power in the hands of foreign changing agents, unrelated to the territory and to the society of Kosovo. State authority was replaced and superseded by the "functional authority" of an international body that managed and governed the territory for a decade.

The classic conception of sovereignty is intrinsically linked to the idea of the State, and assumes that sovereignty is a fixed and exogenous attribute of States. ${ }^{1}$ However, what is easy to conclude from the academic account and the doctrinal perspective is not so easy, however, when it comes to facts and concrete historical situations, sovereignty is subject to very varied interpretations. We believe that it is possible to argue that "there has been a historical tension between state sovereignty, which stresses the link between sovereign authority and a defined territory, and national sovereignty, which emphasizes a link between sovereign authority and a defined population". ${ }^{2}$

No State has the full capacity to dispose of each and every space in which the life and actions of every person subject to it are deployed. No State, therefore, has absolute power over all the fields of action of its members or over all the events that take place in its jurisdiction. However, the fundamental fact is that by claiming "supremacy", the sovereign is not in a po-

1 Tansey, Oisín, “Does Democracy Need Sovereignty?”, Review of International Studies, vol. 37, no. 4, 2011, pp. 1515-1536.

2 Barkin, Samuel and Cronin, Bruce, "The State and the Nation: Changing Norms and the Rules of Sovereignty in International Relations”, International Organization, vol. 48, no. 1, 1994, p. 108. See also Biersteker, Thomas J. and Weber, Cynthia, State Sovereignty as Social Construct, Cambridge University Press, 1996. 
sition to shift the responsibility for his actions to another political space, political-institutional subject or agent, etc. Nearly all States in the world today are based on the idea of popular sovereignty, the idea that the State exists to carry out the will of the people. If the people are formally sovereign, anyone within the State is ultimately responsible for social events. The State provides society with a stable source of power that makes it possible to hold an individual or group responsible for certain political decisions.

This idea raises relevant questions because it implies that the supremacy and inviolability of the State is necessary to guarantee the sovereignty of the people and that if the autonomy of the State is violated, the will of the people is also violated. ${ }^{3}$

\section{The Final Process Towards Kosovo's Independence}

On 17 February 2008 the representatives of the people of Kosovo, acting outside the framework of the United Nations Interim Administration (UNMIK), unilaterally declared the independence of the Balkan territory without violating the constitutional framework or Resolution 1244 (1999) of the Security Council, or any other applicable rule of international law, according to the ICJ Advisory Opinion of July 22, 2010. ${ }^{4}$ The political process for the determination of the status of Kosovo had begun with the involvement of the United Nations, but the impossibility of consensus within the Security Council and between Kosovo and Serbia rendered the efforts for a negotiated solution sterile. After the Declaration of Independence, a number of countries have recognized Kosovo's statehood, of which 22 are part of the European Union, with the exclusion of Slovakia, Spain, Cyprus, Greece and Romania. ${ }^{5}$

The last piece of the itinerary followed by Kosovo in the determination of its status until reaching this Declaration of Independence can be summarized in the following terms.

3 Cunliffe, Philip, "Sovereignty and the Politics of Responsibility", in Bickerton, Christopher J. et al., Politics without Sovereignty. A Critique of Contemporary International Relations, University College London Press, 2007, p. 39.

4 The Advisory Opinion of the International Court of Justice on Conformity with International Law of the unilateral Declaration of Independence of Kosovo can be found in the document of the General Assembly of the United Nations A/64/881, 26 July 2010.

5 For an updated list, see the web page: http://www.kosovothanksyou.com. 
In May 2005, the UN Secretary-General appointed Ambassador Kai Eide as its Special Envoy to Kosovo to carry out a comprehensive review of the province. In a letter addressed to the Security Council on 7 October 2005, in the wake of the so-called Eide Report, the Secretary General concluded that the time had come to move on to the next phase of the political process in Kosovo. On 24 October of that same year the Security Council expressed its support for the beginning of the political process:

The Security Council agrees with Ambassador Eide's general assessment that, despite the problems that still exist in Kosovo and in the region in the broadest sense, the time has come to move on to the next phase of the political process. Accordingly, the Council supports the Secretary-General's intention to initiate a political process to determine the future status of Kosovo, as provided for in Security Council Resolution 1244 (1999). ${ }^{6}$

On 31 October 2005 the UN Secretary General informed the Security Council of his intention to appoint Martti Ahtisaari, former President of Finland, as Special Envoy, to lead the political process on the future legal status of Kosovo, and to appoint Austrian Albert Rohan as deputy to the Special Envoy. The Security Council endorsed the appointments in a letter dated 10 November 2005. ${ }^{7}$

On 15 March 2007 Albert Rohan delivered to the Secretary General the "Final Integral Proposal for the Establishment of the Legal Status of Kosovo" (hereinafter the "Ahtisaari Plan"), accompanied by the Report of the Special Envoy. Both documents were officially forwarded to the Security Council on 26 March and are known as the "Ahtisaari Package", which recommended that Kosovo's status be independence, overseen by the international community. ${ }^{8}$

6 Security Council (United Nations), "Statement by the President of the Security Council", S/PRST/2005/51, 24 October 2005, available at: http://www.un.org/en/ga/search/view_doc. asp?symbol $=$ S $/$ PRST $/ 2005 / 51$.

7 Security Council (United Nations), "Letter Dated 10 November 2005 from the President of the Security Council Addressed to the Secretary-General", S/2005/709, available at: https: / / reliefweb.int/report/serbia/kosovo-letter-dated-10-nov-president-security-council-addressedsecretary-general.

8 Security Council (United Nations), "Report of the Special Envoy of the Secretary-General on Kosovo's Future Status”, S/2007/168, 26 March 2007, available at: https://reliefweb.int/ sites / reliefweb.int/files/resources/4BF3EA59396D0797852572AA007977DO-Full_Report.pdf; Security Council (United Nations), "Comprehensive Proposal for the Kosovo Status Settlement", 
The aim of the Ahtisaari Plan was to define the needs for a viable, sustainable and stable future for Kosovo. It included detailed measures to ensure the promotion and protection of the rights of minorities and their members, the effective decentralization of government and the preservation and protection of cultural and religious heritage. Additionally, the Plan established constitutional, economic and security provisions, all aimed at the development of a multi-ethnic, democratic and prosperous Kosovo. An important element of the Plan was the mandate for a future international civil presence to oversee its implementation and assist the competent authorities in their task of ensuring peace and stability. The Ahtisaari Plan was given hierarchical superiority over the rest of the laws of Kosovo.

Recognizing that fulfilling the Plan was going to require great efforts, an international presence was foreseen to supervise and support the work of the authorities and that it would consist of: 1) an International Civilian Representative (ICR), who will also be the Special Representative of the European Union and will be appointed by the International Steering Group. ${ }^{9}$ This was the ultimate authority to oversee the implementation of the Plan and had specific powers conferred to ensure its success, which included the capacity of nullifying the decisions taken by the Kosovo authorities and sanctioning or dismissing public officials whose actions were contrary to the spirit or the letter of the Plan; 2) a European Security and Defense Mission, which will deal with areas related to the rule of law, police, administration of justice, customs and prisons and may assume additional responsibilities to ensure the maintenance of law and public order; 3) an international military presence of NATO; 4) the OSCE mission, which was requested to assist in the supervision, but which, finally, will remain present without recognizing the validity of the Ahtisaari Plan.

After the entry into force of the document, a transition period of 120 days was foreseen, during which the mandate of UNMIK was to remain in

S/2007/168/Add.1, 26 March 2007, available at: https: / /www.securitycouncilreport.org/atf/cf/ \%7B65BFCF9B-6D27-4E9C-8CD3-CF6E4FF96FF9\%7D/Kosovo\%20S2007\%20168.Add1.pdf.

9 The ICR was appointed by the International Steering Group on 28 February 2008. The International Steering Group was an organization formed by States that supported the total implementation of the Ahtisaari Plan and the independence of Kosovo. Pieter Feith (ex NATO official) was appointed as International Civilian Representative, and simultaneously the Special Representative of the European Union in Kosovo. The ICR mandate was due to continue until Kosovo fulfilled the terms of the agreement, concluded officially on 10 September 2012 with what was called "supervised independence". 
force. During this period, the Parliament, in consultation with the ICR, would approve the Constitution and the necessary legislation, which would be effective as soon as the transition period was over. ${ }^{10}$ At that time the mandate of UNMIK would also expire and all its legislative and executive authority would have to pass in block to the Kosovo authorities. The general and municipal elections were expected to be held within 10 months after the Plan came into effect, and they actually took place.

While the Kosovar authorities tried to carry out the Ahtisaari Plan and conform to the principles and conditions it established, UNMIK ignored the existence of the new Plan and remained unchanged guarding a kind of status quo and showing respect to the "symbolic sovereignty" of Serbia, even after independence was declared. The OSCE, formally a pillar of UNMIK, opted to be neutral and the European institutions were divided with mixed positions. The previous confusion led to a political and social chaos that blocked any significant progress.

The chaos was caused initially by the veto of the UN Security Council, which prevented the approval of the Ahtisaari Plan. The cycle of events was as follows: after the negotiations that began in 2005 and culminated with the presentation in 2007 of the Ahtisaari Plan, a Security Council fact-finding mission visited Brussels, Belgrade, Prishtina andVienna. On 29 July 2007, in view of the permanent differences in the Security Council regarding Kosovo and the subsequent agreement of the Contact Group to continue the process, the then High Representative of the EU for Foreign Policy and Common Security, Javier Solana, appointed the German diplomat Wolfgang Ischinger as a representative of a troika formed by the EU, Russia and the US, responsible for facilitating a compromise between Belgrade and Prishtina on the future of Kosovo.

On 1 August 2007 Ban Ki-moon, then Secretary General of the United Nations applauded the initiative of the Contact Group, adding that "the international community must find a timely solution that addresses the key issues for all minorities living in Kosovo and give clarity to the status of Kosovo. The status quo is not sustainable". ${ }^{11}$ The Troika report of 4 December 2007, created by the Contact Group for Kosovo explicitly acknowledged

10 The Constitution of the Republic of Kosovo was approved on 9 April 2008 and has been in force since 15 June 2008. Available at: http: / / www.kushtetutakosoves.info/?cid=2,1.

11 Secretary General of the United Nations, "Statement on the New Period of Engagement on Kosovo", 1 August 2007, available at: http://www.un.org/sg/statements/?nid=2692. 
that "the parties discussed multiple options, such as total independence, territorial partition, substantial autonomy, confederate agreements, even a silent status of agreement for disagreement... the parties were unable to reach an agreement on the final status of Kosovo". None of them were willing to alter their position on the fundamental question of Kosovo's sovereignty. "This is unfortunate since an agreed status is in the interests of both parties". ${ }^{12}$ Ahtisaari had already warned, in his Report, of such a scenario:

For the past eight years, Kosovo and Serbia have been governed in complete separation. The establishment of the United Nations Mission in Kosovo (UNMIK) pursuant to resolution 1244 (1999), and its assumption of all legislative, executive and judicial authority throughout Kosovo, has created a situation in which Serbia has not exercised any governing authority over Kosovo. This is a reality one cannot deny; it is irreversible. A return of Serbian rule over Kosovo would not be acceptable to the overwhelming majority of the people of Kosovo. Belgrade could not regain its authority without provoking violent opposition. Autonomy of Kosovo within the borders of Serbia - however notional such autonomy may be - is simply not tenable. ${ }^{13}$

In the midst of this situation of paralysis, once the failure of the Troika, which could continue for decades, was verified, Kosovo declared its independence unilaterally, yet backed by the US and the EU. ${ }^{14}$ The Declaration of Independence, proclaimed by the Kosovo Parliament, on behalf of the people of Kosovo, mentions the commitment of the new State to the Ahtisaari Plan.

Through the adoption of the Plan, Kosovo expressed its commitment to democracy and human rights, its resignation to a prolonged international presence in the territory and its acceptance that the Serbian minority and

12 Security Council (United Nations), "Report of the European Union/United States/Russian Federation Troika on Kosovo”, S/2007/723, 10 December 2007, available at: http: / / www. securitycouncilreport.org/atf/cf/\%7B65BFCF9B-6D27-4E9C-8CD3-CF6E4FF96FF9\% 7D / Koso vo\%20S2007\%20723.pdf.

13 Security Council (United Nations), "Report of the Special Envoy of the Secretary-General...”, cit., p. 3.

14 In the weeks previous to the Declaration of Independence, a number of articles were published about the willingness to recognize a potential new State of Kosovo in several North American and European media. See Vidmar, Jure, “International Legal Responses to Kosovo's Declaration of Independence”, Vanderbilt Journal of Transnational Law, no. 42, 2009, p. 804. 
its church would enjoy wide privileges. But Kosovo, by signing the Ahtisaari Plan, also took over the obligations contracted up to that moment in its name and which allowed restrictions on its sovereignty. When the Constitution of the Republic of Kosovo entered into force on June 15, 2008, it also subscribed to the prescriptions of the Ahtisaari Plan, confirming the limitations of the recently inaugurated sovereignty. A perfect example of this is article 153 of the Constitution:

Notwithstanding the provisions of this Constitution, the International Military Presence shall possess the mandate and authority provided for in international instruments, including the Resolution of the United Nations Security Council 1244 and the Comprehensive Proposal of Agreement on the Statute of Kosovo dated March 26, 2007. The Head of the International Military Presence will be, in accordance with the Comprehensive Proposal for an Agreement on the Statute of Kosovo of March 26, 2007, the ultimate authority on the scene regarding the interpretation of the aspects of the aforementioned Agreement that refer to the International Military Presence. No authority of the Republic of Kosovo shall have jurisdiction to review, diminish or restrict the mandate, powers and obligations referred to in this article. $^{15}$

Kosovo was still far from having detached itself from international control. After independence, the mission of the European Union EULEX was deployed in the territory. EULEX was born with the Ahtisaari Plan, but the lack of approval from the Security Council made it necessary to dissociate itself from the Plan and adhere to the framework of Resolution 1244 (1999) of the Security Council.

\section{2. $E U L E X$}

The European Union Rule of Law Mission in Kosovo (EULEX) is the largest civil mission organized by the EU's Common Security and Defense Policy. ${ }^{16}$ Its official objective was to assist and support the Kosovo authorities in the areas connected to rule of law, specifically police, administration

15 Constitution of Kosovo.

16 Almost all the members of the EU as well as Norway, Switzerland, Turkey, Croatia and Canada contribute to the mission. 
of justice and customs. Unlike UNMIK, the Mission was not launched in Kosovo to govern or legislate, it was meant as a technical mission that should supervise, train and advise local authorities, ensure public order, combat corruption, fraud and financial crimes and ensure that serious crimes were investigated and prosecuted while retaining a number of executive powers, which officially ceased in June 2018. From that point, EULEX remained with a reduced mandate of supervision and support. ${ }^{17}$ The executive powers focused on the areas of police and justice and included major investigations and judicial procedures, but they included as well the disavowal of the decisions of local authorities and the possibility of making decisions prevailing over them.

As mentioned before, the EU accepted Serbia's demand (backed by Russia) not to implement the Ahtisaari Plan through EULEX, which would remain neutral with respect to Kosovo's status, in this way EULEX was accepted by both Serbia and by the Security Council. ${ }^{18}$

Therefore, EULEX works within the general framework of Resolution 1244 and has a direct unified chain of command with Brussels. ${ }^{19}$ On 25 August 2009, EULEX was subject to violent protests, which caused damage to 28 official vehicles by Kosovo-Albanians who were against an international presence that violated the sovereignty of Kosovo. Three policemen were

17 The initial mandate expired on 14 June 2012, but has been extended several times. See European Union Council, “Council Decision (CFSP) 2018/856 Amending Joint Action 2008/ 124/CFSP on the European Union Rule of Law Mission in Kosovo”, available at: http: / /www. eulex-kosovo.eu/eul/repository/docs/CouncilDecision-203336.pdf.

18 The long path of EULEX to be accepted, and its place in the mandate of Resolution 1244, is explained in detail in Wet, Erika de, "The Governance of Kosovo: Security Council Resolution 1244 and the Establishment and Functioning of Eulex", The American Journal of International Law, vol. 103, no. 1, 2009, pp. 83-96. On EULEX, see Greiçevci, Labinot, "EU Actor in International Affairs: The Case of EULEX Mission in Kosovo", Perspectives on European Politics and Society, vol. 12, no. 3, 2011; Richter, Solveig, "Promoting Rule of Law without State-Building: Can EULEX Square the Circle in Kosovo?", in Asseburg, Muriel and Kempin, Ronja, The EU as a Strategic Actor in the Realm of Security and Defense? A Systematic Assessment of ESDP Missions and Operations, Stiftung Wissenshaft und Politik, Research Paper 2009/RP 14, December 2009; Džihić, Vedran and Kramer, Helmut, “Kosovo After Independence. Is the EU's EULEX Mission Delivering on its Promises?”, International Policy Analysis, Berlin, 2009, available at: https: / / library.fes.de/pdf-files/id/ipa/06571.pdf.

19 See, among others, Spernbauer, Martina, "EULEX Kosovo: The Difficult Deployment and Challenging Implementation of the Most Comprehensive Civilian EU Operation to Date", German Law Journal, vol. 11, no. 8, 2010. 
injured and 21 arrests were made. There is resentment towards EULEX for exercising its executive powers in the newborn country while trying to mediate between Kosovo and Serbia, and a deep sense of deception because of the European Commission's final submission to Resolution 1244. Its policies focused on crisis management rather than in its resolution, and the claim of ethnic autonomy and its extensive mandate on the governance of Kosovo are added causes of discontent with EULEX.

However, and fortunately, an independent Kosovo allows us to observe legal figures and political phenomena that go beyond its relationship with external powers, which have their origin in the Kosovar system itself. In this sense, we consider it necessary to examine the approach and the reflection, although brief, of the characteristics of what could be identified as the "basic norm", or Grundnorm, of the Kosovar legal system.

\section{The GRUNDNORM OF THE KOSOVAR LEGAL SySTEM}

What the Ahtisaari Plan proposed for Kosovo could be qualified as a category of "conditional independence". To achieve this independence, Resolution 1244 had to be repealed. ${ }^{20}$ As described, due to constant disagreements between the US and Russia, the Plan did not achieve the approval of the Security Council, leaving Resolution 1244 formally in force. However, the validity of the Resolution can be questioned, given the completion of the mandate it contains and the new legal and political reality existing in the domestic and international spheres. It could be concluded, then, that the Ahtisaari Plan offered a conditional statehood to Kosovo, at least in a substantive legal context. And, in any case and in spite of this conditionality, it is evident that the hugely relevant political consequence of the Plan was the authorization to adopt a Constitution recognized by the people of Kosovo.

Unlike what happens in western models, an important debate arises in Kosovo about the supremacy of the Constitution in the legal order. According to Doli and Korenica, which are based on Hans Kelsen's theories on the Grundnorm, there is a fork, a divergence, in the Grundnorm of Kosovo between

20 The term "conditional independence" can be found in multiple texts, for example, Tansey, Oisín, "Kosovo: Independence and Tutelage”, Journal of Democracy, vol. 20, no. 2, 2009. 
the Constitution and the Ahtisaari Plan, which suggests that the validation of norms in the legal system of Kosovo has been carried out by distributing the work between both texts. The analysis of these authors focuses on the revision of the relationship between both texts - Constitution of Kosovo and Ahtisaari Plan $-{ }^{21}$ and more specifically, in elucidating which of them is the highest ranking. It is appropriate to remember Hans Kelsen. When he talks about the Grundnorm, in the Pure Theory of Law, he says:

This norm, presupposed as the basic norm, supplies both the reason for the validity and the content of the norms deduced from it in a logical operation. A system of norms, whose reason for validity and content is deduced from a norm presupposed as a basic norm is a static norm system... However the norm from whose content the other norms are deduced in the described fashion can be regarded as basic norm only if its content is assumed to be directly evident. ${ }^{22}$

And he adds:

(T)he basic norm is that norm which is presupposed when the custom through which the constitution has come into existence, or the constitution-creating act consciously performed by certain human beings, is objectively interpreted as a norm-creating fact; if, in the latter case, the individual or the assembly of individuals who created the constitution on which the legal order rests, are looked upon as norm-creating authorities. In this sense, the basic norm determines the basic fact of law creation and may in this respect be described as the constitution in a logical sense of the word... in contradistinction to the constitution in the meaning of positive law. The basic norm is the presupposed starting point of a procedure: the procedure of positive law creation. ${ }^{23}$

The Constitution of Kosovo declares itself to be the highest legal act of the Republic of Kosovo, hierarchically superior to any law. In the same way as other continental European Constitutions, it states that the power to govern arises from the Constitution; assumes the respect to international law

21 Doli, Dren and Korenica, Fisnik, "What about Kosovo's Constitution: Is There Anything Special?”, Vienna Journal of International Constitutional Law, vol. 5, no. 1, 2011, p. 54.

22 Kelsen, Hans, Pure Theory of Law, 2nd. ed., trans. of Max Knight, New Jersey, The Lawbook Exchange, 1967-2005, pp. 195 and 196.

23 Ibidem, p. 199. 
and declares that any person or entity in the Republic of Kosovo is subject to the provisions of the Constitution. ${ }^{24}$

The Constitution, therefore, is proclaimed and established as the source and summit of the entire legal system, but also specifies that notwithstanding the provisions of the Constitution, the authorities of the Republic of Kosovo will comply with the obligations established in the Ahtisaari Package and take all necessary actions for its implementation. In a similar line, the Constitution states that the provisions of the Ahtisaari Package will take precedence over any other legal provision in Kosovo; the Constitution, laws and any legal acts of the Republic of Kosovo will be interpreted in compliance with the Package and in case there are inconsistencies between the Constitution, the laws or any legal acts of the Republic of Kosovo and the provisions of the said document, this last shall prevail. ${ }^{25}$

In the opinion of Doli and Korenica, these paragraphs set out the essential internal conflict of the Constitution of Kosovo, which is proclaimed as the supreme legal act while declaring that the Ahtisaari Plan will be put above the Constitution. The authors then ask whether there is a possibility that a Constitution is the superior legal act, that it provides validity to the rules of the system, while subordinating itself to another act with legal meaning and conclude that the answer lies in the analysis of the Ahtisaari Plan as a legal act, the examination of the matters it regulates and whether it grants validity to other legal norms of the Kosovar legal system. This seems to be the way to identify the "basic norm" of the current legal system of Kosovo.

The Ahtisaari Plan stipulates a series of rules that will preside the internal governance of Kosovo, announces independence as the appropriate model, establishes international limits, establishes rights and duties for citizens and prescribes obligations in relation to the material contents of the future Constitution of Kosovo. The Plan, therefore, responding to the issue of the matters it regulates, includes constitutional matters and with respect to the question of whether it grants validity to other norms, does so by virtue of article 143 of the Constitution of Kosovo.

In the substantive context, it can be argued that the Ahtisaari Plan possesses legal attributes, even of constitutional rank. But the important question of whether it is conceptually possible to consider the Plan as a properly legal act remains closely linked and conditioned, ultimately, to the consideration

24 Constitution of Kosovo, article 16.

25 Ibidem, article 143. 
and assessment that is appropriate to attribute to the procedure followed in its adoption. The Plan was never approved by the United Nations or by any international organization, and it is not even possible to show the support of an express multilateral agreement. What, then, is the source of legitimacy of the Ahtisaari Plan? The legal authority of the document comes from a single source:The Constitution of Kosovo. Therefore, the Ahtisaari Plan cannot properly be considered the basis of validity of the Constitution, although the Ahtisaari Plan authorizes its adoption, it did not have the legal power to do so. According to Doli and Korenica, it is the Constitution that serves as the basis of validity for the Ahtisaari Plan. ${ }^{26}$

If we may be allowed an explanatory simplification, the conclusion would be, therefore, that the Constitution of the Republic of Kosovo, perhaps far from the "classical" constitutional model, stands as the "basic norm", and

(G)iven that the Ahtisaari Plan acquires its foundation and can be applied through the Constitution, this norm cannot be subordinated to the Plan. This argument follows the logic of the theory of the Grundnorm, since the power of an act (the Ahtisaari Package) cannot be derived from an inferior act, given that the validity of the acts, or the attribution of binding force, can occur only if it comes from a higher legal basis. Therefore, although the Constitution recognizes the supremacy to the Ahtisaari Plan, it cannot really do so. Only if the Ahtisaari Plan had been approved by an international organization or by the domestic authority, would this have been possible. But since the Ahtisaari Plan has not been approved internally or internationally, except for the Constitution of Kosovo, no primacy can be asserted for the Constitution... That is to say, the Constitution, like the Kelsenian Grundnorm, cannot grant supremacy to the Ahtisaari Plan and at the same time be the source of that supremacy. ${ }^{27}$

We are undoubtedly facing one of the oldest and most complex issues that have occupied and greatly concerned the philosophy of law and the contemporary State, a powerful reason to avoid improper simplifications and to reject any temptation to theoretical frivolity.

But we need to advance our discrepancy with respect to the conclusion outlined above, insofar as we understand that it is not conceptually possible to consider the Constitution of Kosovo as the Grundnorm of its legal system,

26 Doli, Dren and Korenica, Fisnik, op. cit., p. 50.

27 Ibidem, p. 57. 
or at least, as the source of validity of this system. We must conclude that it is not its Constitution, classical or not, bifurcated or supreme, but the Declaration of Independence of Kosovo, which stands as a source of legitimacy and validity of the Kosovar legal system. As the International Court of Justice ruled:

(T)he authors of the Declaration of Independence of 17 February 2008 did not act as an interim institution of self-government within the Constitutional Framework, but as persons acting jointly, in their capacity of representatives of the Kosovo people, outside the framework of the provisional administration. ${ }^{28}$

It can be argued, with not many difficulties, that these representatives of the people of Kosovo stand as a constituent power at the moment of signing the Declaration of Independence, which is the source of legitimacy of all the norms and legal principles of the Kosovar legal system.

\section{RECOGNITION OF STATES AND THE CONTRAVENTION OF IUS COGENS RULES}

The recognition of States has always been permeated by competing doctrines about the constitutive and declaratory character of recognition. The contraposition of these two doctrines dominates the discussion on the subject.

The constitutive theory of recognition of States sees the act of recognition as a necessary precondition for the survival of a State's capabilities. Its practical effect is not to attribute international legal personality to the "State" not recognized by the international community. ${ }^{29}$

As Talmon explains:

The constitutive theory is an expression of an outdated, positivist view of international law as a purely consensual system, where legal relations can only arise with

28 Advisory Opinion on Kosovo..., cit., p. 43.

29 Dal Ri Júnior, Arno and Carnesella, Gustavo, "El reconocimiento de nuevos Estados como sujetos en la ciencia del derecho internacional a partir de la deflagración de la Segunda Guerra Mundial: abordajes doctrinarios de la Convención de Montevideo a la «Opinión Consultiva Kosovo» (1933-2010)", Anuario Mexicano de Derecho Internacional, vol. 17, 2017, pp. 513-546. 
the consent of those concerned. From this point of view, fulfilling the conditions for statehood alone does not suffice to render an entity a subject of international law, thus leaving the non-recognized State without rights and obligations vis-à-vis the non-recognizing States; in other words, international law does not apply between them. ${ }^{30}$

The predominant view is the one that considers that state recognition just "establishes, confirms or provides evidence of the objective legal situation". ${ }^{31}$ Therefore "the international legal personality of a State and its concomitant rights and obligations solely depend on it being able to satisfy the criteria for statehood". 32

Many countries have recognized Kosovo and have mentioned, in their recognition texts, the oppression and violence suffered by its population under Serbian rule. However, remedial secession explanation seems far from the Kosovo case because secession happened almost ten years after oppression and Serbian rule ended. If independence had happened in 1999, after the NATO humanitarian intervention, this argument could have been accepted. ${ }^{33}$ In any case, "the remedial secession doctrine not only has weak theoretical foundations, but also no support in state practice". ${ }^{34}$

It could be discussed that, in this case, a kind of non-recognition obligation may operate, due to Kosovo being born as a State in alleged violation of ius cogens rules, referring to the illegal NATO intervention that took place in 1999. The humanitarian intervention in Kosovo was not approved by the United Nations' Security Council, therefore its legality cannot be defended in accordance with the United Nations Charter. One of the results of this armed intervention was the de facto separation of Kosovo and the absolute loss of Serbian control over the territory. ${ }^{35}$

30 Talmon, Stefan, "The Constitutive versus the Declaratory Theory of Recognition: Tertium Non Datur?”, British Yearbook of International Law, vol. 75, no. 1, 2004, p. 102.

31 Ibidem, p. 105.

32 Ibidem, p. 106.

33 Vidmar, Jure, "Remedial Secession in International Law: Theory and (Lack of) Practice", St. Antony's International Review, vol. 6, no. 1, 2010, p. 49.

34 Ibidem, p. 37.

35 Jara Gómez, Ana M., "Soberanía, guerras justas y responsabilidad de proteger”, Criterio Jurídico, vol. 16, no. 2, 2016, p. 180, available at: https://revistas.javerianacali.edu.co/index.php/cr iteriojuridico/article/view/2127. On humanitarian intervention, see Mayall, James, "Humanitarian Intervention Revisited”, in Buckley, Mary and Cummings, Sally N. (eds.), Kosovo. Perceptions 
But it must be said the case of Kosovo is an example of intervention undertaken, among other things, to save a people at risk of annihilation, and also an example of multilateralism, as opposed to the decisions of a single attacking power based on particular reasons. Nineteen powers, almost all of them of Christian tradition, intervened to protect a Muslim minority from the attacks of a Christian-majority state. The speed of the Serbian assault on the Kosovars, once the bombing began, seemed to confirm that ethnic cleansing was the Serbian target, just as it had been shortly before in Bosnia and Herzegovina, where Serbia perpetrated a genocide. ${ }^{36}$

Judge Bruno Simma stated there are "hard cases" involving terrible dilemmas in which imperative moral and political considerations leave no alternative but to act outside the law. Of course, if these instances become generalized, they have the power to undermine the entire system of collective security. ${ }^{37}$ In an even stronger defense of the legitimacy of NATO's actions is offered by Judge Cassese, who argued:

(A)ny person of common sense is justified in asking him or herself the following dramatic question: Faced with such an enormous human-made tragedy and given the inaction of the UN Security Council due to the refusal of Russia and China to countenance any significant involvement by the international community to stop the massacres and expulsions, should one sit idly by and watch thousands of human beings being slaughtered or brutally persecuted? Should one remain silent and inactive only because the existing body of international law proves incapable of remedying such a situation? Or, rather, should respect for the Rule of Law be sacrificed on the altar of human compassion $?^{38}$

of War and its Aftermath, Great Britain, Bookends Ltd., 2001, pp. 266-276; Murphy, Sean D., Humanitarian Intervention:The United Nations in an EvolvingWorld Order, Philadelphia, University of Pennsylvania Press, 1996; Holzgrefe, J. L. and Keohane, Robert E. (eds.), Humanitarian Intervention Ethical, Legal, and Political Dilemmas, Cambridge University Press, 2003; Kreß, Christian, When Is Military Intervention Morally Justified?, Norderstedt, Grin Verlag für Akademische Texte, 2005.

36 International Criminal Tribunal for the Former Yugoslavia (ICTY), Prosecutor v. Radislav Krstic, Srebrenica-Drina Corps, case IT-98-33 (Krstic Trial Chamber Judgment and Krstic Appeals Chamber Judgment).

37 Simma, Bruno, "NATO, the UN and the Use of Force: Legal Aspects", European Journal of International Law, vol. 10, 1999.

38 Cassese, Antonio, “Ex Iniuria Ius Oritur: Are We Moving Towards International Legitimation of Forcible Humanitarian Countermeasures in the World Community?”, European Journal of International Law, vol. 10, 1999, p. 25. 
We understand that it is not a matter of sacrificing the law on the altar of compassion; it is a matter of defending the law in the face of political interests, which prevent it from acting. If China and Russia had voted in favor of intervention, it would have been immediately legal, the situation in Kosovo staying exactly the same. Therefore, it is not what is happening in Kosovo that calls into question the Rule of Law. ${ }^{39}$

However, because respect for human rights standards was imposed in serious breach of the procedural rules of international law, the intervention was, and this cannot be doubted, illegal.

Mention must be made, however briefly, of the contradiction concerning the existence of ius cogens rules, which, unlike most international rules, cannot be derogated or changed by a treaty. Rules of ius cogens are defined precisely because they can only be overturned by another rule of ius cogens, so that for a behavior not in conformity with such rule to become legal there is no other way than illegality.

The possibility of a conflict between ius cogens rules is not meta-legal speculation, the prohibition of intervention and the prohibition of committing genocide express this conflict well. The rules dealing with the unlawful use of force are the first to be highlighted by the International Law Commission as an example of ius cogens rule, and large-scale violations of human rights appear to be on the same level. This conflict seems unsolvable. One thesis that emerges coherent to us is that in case there is a clash of two ius cogens norms, one norm may have developed the other through the acts that violate it. ${ }^{40}$ The issue may be considered from the perspective of the appropriate normative scope of each of them. This, in the case of the NATO intervention in Kosovo, would mean that the right of a State to be immune from unilateral armed intervention by another State or group of States exists only insofar as the intervened State has not itself violated the ius cogens norm which forbids it from massively violating certain human rights obligations which are themselves ius cogens norms. Otherwise, humanitarian countermeasures could be accommodated in this context. ${ }^{41}$

39 Jara Gómez, Ana M., Kosovo en el laberinto. Estado, derecho y derechos, Granada, Comares, 2019.

40 Rodley, Nigel S. and Çali, Başak, "Kosovo Revisited: Humanitarian Intervention on the Fault Lines of International Law”, Human Rights Law Review, vol. 7, no. 2, 2007, p. 291.

41 Ibidem, p. 292. There are authors who, admitting the absence of a legal basis in the United Nations Charter for unilateral humanitarian intervention, argue that such interventions 


\section{Kosovo From Spain: The PERVERSION \\ OF A BIASED GAZE}

In our opinion, views on the Balkans, and particularly those directed at Kosovo, have often been conditioned by opportunistic ad hoc instrumentalizations or by partial acceptances with reservations, all too often neglecting the inescapable perspective of human rights or the more specific ones of the interests of the population directly affected. In this sense, the Spanish gaze has not been, and to this day still is not, free of such bias, constituting a sui generis version of its foreign policy of security and cooperation. Spain, unlike most of its European partners, including countries with recognized territorial problems such as the United Kingdom or Belgium, opted to yield its position on Kosovo to the territorial nervousness of its internal policy. The issue of Spanish position on Kosovo is so simple that, neither in substance nor in form, neither in its official version nor in its unofficial version, seems worth much interest.

However, there are issues that, once installed in the field of sociopolitical practice or in the field of theoretical-doctrinal debate and beyond its intrinsic relevance and interest for the question in hand, acquire such a level of insistence and repetition that their treatment ends up being forced or, to the contrary, their circumvention requires, inescapably, a justifying explanation.

Without reaching the levels of a large public debate and without properly generating a soundly-based rigorous theoretical reflection, it is true that the Spanish position on Kosovo has been controversial, sometimes bitter, often emotion-filled, not always coherently argued and generally analyzed in connection with the internal territorial issue and, more specifically, with the problem of the Catalan independence movement. A sort of political strabismus takes place in Spain when looking at Kosovo.

It is generally known that Spain, after the fierce war in Kosovo, participated decisively and actively, for practically a decade, in the pacification, security and stability plan, deployed by NATO forces in the territory (KFOR),

are permitted under customary international law. See Wheeler, Nicholas J. and Bellamy, Alex J., "Humanitarian Intervention in World Politics", in Baylis, John and Smith, Steven (eds.), The Globalization of World Politics: An Introduction to International Relations, Oxford, Oxford University Press, 2008, p. 525. 
pursuant to Resolution 1244 (1999) of the UN Security Council. It is also known that, in the month of March 2009, after ten years of military cooperation and more than a year after the unilateral Declaration of Independence by Kosovo, Spain announced abruptly, in open dissonance with NATO, with the United States, with its EU partners and with the Kosovo authorities themselves, the unilateral decision to withdraw its troops from Kosovo, generating a climate of confusion, perplexity and international bewilderment.

Spain certified in this way, and perhaps here lies the true dimension of the fact, an evident shift of its traditional foreign policy of security and cooperation, aligned until then with its European partners, and installed in the score of domestic politics, riskily submitting the external policy to the requirements of a purely domestic political-electoral conjuncture. It cannot be concealed from anyone that the Spanish government, established a year before, after the general elections of March 2008, in whose electoral campaign it had carefully avoided the issue of Kosovo, ${ }^{42}$ was already immerse in a context of acute economic-financial crisis and it was rapidly entering into a deep political crisis, in which the territorial debate was no minor matter.

Although some public statements can be dated prior to 2009, it is from the moment described that the position of Spain is made explicit with greater clarity, without excluding, given its genuine complexity, certain inconsistencies and some contradictions.

The truth is that Spain has been confusingly arguing, and continues to do so, that the objectives of peace and stability pursued in Kosovo have been met, that it maintains its will to continue contributing to security and stability in the region, which is not coherent to participate in tasks of "national construction" whose international legality it does not recognize and that recognizing a unilateral Declaration of Independence within the European territorial framework sets a dangerous precedent, with clear and direct impact on the Basque Country and Catalonia. Far from such argument we want to remember the epic description that was made in Revista Española de

42 See "The Revelations of WikiLeaks", El País, 12 April 2010. Here it can be read that the acting government did not want to speak on the matter "before the elections", and its spokesperson "wants the issue out of the headlines", although leaving explicit evidence that, "if the candidate Zapatero is re-elected, it would be open to continue dialogue on cooperation with the United States aimed at a consensus of the European Union to achieve peace and stability in the Balkans". This is true, and thus it is recognized, that Spanish support of the unilateral Declaration of Independence on the part of Kosovo, was neither politically possible nor realistic “...in the midst of a much disputed campaign”. 
Esta revista forma parte del acervo de la Biblioteca Jurídica Virtual del Instituto de Investigaciones Jurídicas de la UNAM

Defensa, ten years ago, on the presence and objectives of Spain's troops in the area, responding to the "cry of the most basic human feelings" and to the "new course that the defense policy has taken, more in line with the place that Spain occupies today in the world". ${ }^{43}$

A brief review of the official statements on the Spanish decision to modify its role in Kosovo, and a superficial glance at the newspaper archives, forced by the prominence assigned to the matter in the media, allows us to appreciate the inadequacy of the argument at the same time that it fully confirms, in our understanding, the political turn to which we have referred. It is true that there have been voices critical to the official discourse, which have fought the spurious assimilation of Kosovo with Catalonia, have claimed greater doses of prudence and nuances in the Spanish position, have suggested the need to formalize some Spanish presence in Kosovo, have highlighted the need to re-attune to the majority position in Europe and, above all, have questioned any attempt by Spain to intone any "irritating chant to the moral and political superiority of the Spanish position compared to the rest of the European advanced democracies". ${ }^{44}$

However, the fact is that more than ten years have passed since Spain left Kosovo and nothing has changed its position. Neither the alterations in the Spanish political map, nor the movements in EU policy, nor the repeated pronouncements from the Balkan country, have altered the Spanish position,

43 Together with the detailed and emotional account of visits to Spanish troops by the President of the Government and his Minister of Defense, headed by the banner "Thank You Spain", held at the southern exit of the Spanish base in Istog, it is worth mentioning the strong and committed message from the Chief Colonel of the Spanish contingent in Kosovo and Second Chief of the West Sector of KFOR: "Our mission is to give security and guarantee to the people that Kosovo has a future... we must contribute to rewrite the history of this country". Revista Española de Defensa, no. 137-138, July-August 1999, pp. 6-8.

44 Taibo, Carlos, "Los horizontes para Kosovo”, El País, 15 April 1998; Taibo, Carlos, “ ¿Y por qué no un Kosovo independiente?”, El País, 18 April 1999; Taibo, Carlos, "Incomodidades kosovares", El Correo, 3 January 2008; Taibo, Carlos, "Kosovo y las esencias”, Público, 16 February 2008. See also Molina, Ignacio, "Kosovo como problema. Europa, la solución”, El País, 15 December 2010; Molina, Ignacio, "Kosovo y Cataluña: distintos y distantes”, Real Instituto Elcano, 6 December 2012; Vaquer i Fanés, Jordi, “Kosovo avanza, pese a las dificultades”, Opinión CIDOB, no. 95, 17 December 2010; Manzano, Cristina, “¿A quién le importa Kosovo?”, Huffington Post, 10 May 2013; Vidal Folch, Xavier, "Cataluña no es Kosovo”, El País, 13 August 2017; Fernández Ibáñez, Miguel, "Kosovo, el Estado medio fallido que se siente traicionado”, Público, 17 February 2018; Altares, Guillermo, "El problema de Kosovo es su excepcionalidad”, El País, 4 May 2018; Carnicero, Carlos, "Kosovo: una china en el zapato de Rajoy”, Huffington Post, 17 May 2018. 
apparently monolithic and politically peaceful. Simplifying things, one might think that Spain looks at Kosovo and sees the secessionist Catalonia and the Basque Country; and pro-independent Catalonia looks at Kosovo and sees itself. Spain continues then, not to see Kosovo.

Officially, no one sees Kosovo anymore in the midst of violence, ethnic cleansing, persecution and war; no one sees, officially, genocidal practices, the systematic violation of human rights, the plundering and destruction of the productive industry; no one, officially, sees Kosovo as a European matter.

Spain, once the champion of a European common foreign and security policy, has ended by imposing a perverse utilitarian and instrumental logic that breaks with the common European policy, disregards the defense and protection of human rights and blatantly forgets the sovereign will "to collaborate in the strengthening of peaceful relations and effective cooperation among all the peoples of the Earth", proclaimed in the preamble to the Spanish Constitution.

At this point, it may be necessary to conclude that only fear, ignorance or cynicism may attribute to Kosovo the enormous capacity that seems to be presumed from Spain. As professor Ignacio Molina pointed out, "mismanaged domestic interests and fears" have contributed to the loss of the values traditionally present in our foreign and cooperation policy. ${ }^{45}$ And perhaps, in a commendable mental effort to comprehend, someone can come to understand how, if it is admitted and proclaimed insistently by politicians and government officials, that Catalonia is not Kosovo, why does the official discourse of our foreign policy assimilate them openly, until granting the young Balkan State the status of inadmissible precedent for Catalonia? When one approaches the Spanish discourse about Kosovo, it is difficult not to evoke the novel stupidity, denounced by Hannah Arendt in her well-known "Reflections on the Pentagon Papers" consistent in making politics by disregarding the facts and giving satisfaction simultaneously to "diverse audiences" or "relevant audiences", by making images aimed at "winning the people's minds". ${ }^{46}$

45 Molina, Ignacio, "Kosovo como problema, Europa como solución y la incidencia del Informe Marty”, Aquiescencia, 21 December 2010, available at: https: / / aquiescencia.net/2010/12 / 21 / kosovo-como-problema-europa-como-solucion-y-la-incidencia-del-informe-marty-por-ignaciomolina/.

46 Arendt, Hannah, "La mentira en política. Reflexiones sobre los documentos del Pentágono”, Verdad y mentira en la política, Barcelona, Página Indómita, 2017, pp. 105-108. 
The remarkable bursting into the Spanish national scenario of the doctrinal requirements of the old legal dogmatic deserves special attention. Dogmatic was deployed in this case around the two classic structural principles of international law: sovereignty and territorial integrity of States and selfdetermination of peoples. Though we cannot obviously go into great detail, the treatment given by an important sector of Spanish doctrine to the ICJ Advisory Opinion on Kosovo is striking. It is true that also in this area, Spain has played a poor role, but perhaps this is not sufficient reason for such an enraged and distasteful reaction of the country's doctrine. ${ }^{47}$ These ardent doctrinal explosions are not infrequent, but attributing legal inconsistency, politicization and irresponsibility to an international advisory and non-binding jurisdiction is, in itself, suspicious. Further, it negates the composing and promotional function of the law, evokes old natural rights and, of course, an almost sacred conception of the jurisdictional function transpires.

It would be unfair not to recognize the existence of more temperate doctrinal positions, which have highlighted the appeasing, pragmatic and constructive effect of the Advisory Opinion of the ICJ. For this sector, perhaps a minority, the ICJ's option to reconcile the denial to the existence of a right to unilateral secession with the "thesis of exceptionality", boosting the protection of human rights as a backdrop, contains a doubtless promising doctrine. Neither the doctrine of "remedial secession" nor the thesis of the right of "secession as sanction" can equal it in advantages and it may end up being the most useful thesis to respond to the concerns in which the current movement of the Spanish position on Kosovo is heading. After all, "nor will the defenders of the Spanish unity be able to use the example of the Serbian attitude... nor can the independence fighters use the case of Kosovo as a symbol or model to follow". ${ }^{48}$

47 See Jiménez Piernas, Carlos, "Los principios de soberanía e integridad territorial y de autodeterminación de los pueblos en la Opinión Consultiva sobre Kosovo: una oportunidad perdida”, Revista Española de Derecho Internacional, vol. 63, 2011; Gutiérrez, Cesáreo and Bermejo, Romualdo, "De la Opinión Consultiva de la Corte Internacional de Justicia, de 22 de julio de 2010, sobre Kosovo" (Documento de trabajo, 35/2010), Real Instituto Elcano, 10 November 2010; López-Jurado, Carmen, "Kosovo ante la Corte Internacional de Justicia: la Opinión Consultiva de 22 de julio de 2010”, Revista Electrónica de Estudios Internacionales, vol. $21,2011$.

48 Rizzi, Andrea, "Kosovo: una década de independencia, una odisea inacabada hacia el Estado de derecho”, El País, 16 February 2018. 
Kosovo, in the midst of enormous difficulties, continues advancing in the normalization of its relations with Serbia, in the consolidation of the Kosovar institutions of self-government and in the reconstruction of its productive industry and economy. From the point of view of its external effectiveness, therefore, it can be concluded that Kosovo is a viable State, which today can be linked, as a State, with over 110 countries.

The International Court of Justice made clear, as mentioned before, that Kosovo's Declaration of Independence was neither contrary to general international law, nor to Resolution 1244, of the Security Council, nor to its own constitutional framework. Faced with the rigid Spanish argument, based on an alleged violation of international law, it is not necessary to remember that violations of international law do not vary according to the State from which they are analyzed, since there is no Finnish, Russian or Spanish international law. If there were various international laws depending on the States, in addition to being a flagrant contradiction in terms, it would suppose the denial of the international order itself.

\section{FinAL REMARKS}

Kosovo deserves a more extended analysis and more reflection than it is authorized by the interested, accommodating and immoral use of violence, persecution, violation of human rights and the lack of freedoms suffered by others. But at this point in the story, Spain must know that Kosovo has not transitioned smoothly to independence nor has it been precisely a bed of roses. Nor has international support been given for free either. Kosovo did not reach its independence, after years of apartheid and a bloody war, without first experiencing the harsh effects of a severe "reconstruction", during which the EU carried out the privatization of practically all of Kosovo's public companies, sold at fire sale prices to companies of member countries. The former province suffered the administration of its territory, while the US-built Camp Bondsteel, the largest military base in the world, in Ferizaj. To date, the social and economic situation is recovering very slowly, maintaining unemployment rates of $30 \%$ (50\% in young people). ${ }^{49}$

49 See document titled "Enlargement Countries - Labour Market Statistics", by Eurostat, available at: https://ec.europa.eu/eurostat/statistics-explained/pdfscache/32178.pdf. 
The Spanish view on Kosovo is not a minor issue, neither for Kosovo, nor for Spain nor, of course, for Europe. Kosovo remains present in the agenda of Europe, but has practically disappeared from the Spanish public agenda, except for exhibition of actions of denial, opposition and veto.

The active and principled opposition of Spain to the recognition of Kosovo, suitably fueled by separatism whenever it publicly invokes the precedent of the Balkan country, hinders its aspirations of normality and constitutes a constant source of tension and controversy. Non recognition prevents Kosovo from being member, together with other countries of the region, of the international and European processes of democratization and development. Foreign private investment is paralyzed, as well as the possibility of credit from global institutions of which it cannot be a member. Organized crime cannot be fought properly without cross-border cooperation and Kosovo is unable to sign certain cooperation agreements, even to protect its valuable historical-artistic heritage. For citizens, the problem of valid passports and obtaining visas has made mobility, and often business, very difficult. The European citizens of Kosovo, who keep their trust in us intact, do not understand Spain's stance.

In the spring of 2009, as soon as the withdrawal of the Spanish troops from Kosovo was announced, I was asked, by a senior official of the Town Council of Peja, to translate a journalistic text that he wanted to publish in Spain. The document contained the emotional historical evocation of a young Kosovar, Xhemail Kada, who had fought and died in the Spanish Civil War, in defense of the Spanish Republic and of "those values and principles that no one should ever be forced to abandon under any kind of oppression, violence or persecution", and that the author associated the spirit with which Spain's troops had camped and acted in Kosovo. The text included a regret for the sad news of the withdrawal of the Spanish soldiers "without the honors that we would have wanted... and without even giving us the opportunity to thank them", and ended with a puzzled and disconcerting question: "Why, if for ten years they have defended us from inhumane aggressions and have effectively and exemplarily protected our freedom, are the Spanish soldiers now leaving suddenly?". ${ }^{50}$

It is desirable that Spain assumes its role in European foreign policy, and it is foreseeable that this will happen sooner rather than later. Meanwhile, it

50 Sahiti, Naim, “The Xhemail Kada School. From Kosovo with Sadness”, La Opinión de Granada, 8 April 2009. 
may not seem realistic to demand the immediate normalization of the Spanish political outlook on Kosovo. But those who, in good faith, keep alive the desire and the active will to achieve it, must first be aware that no "biased look" is politically innocent.

\section{BIBLIOGRAPHY}

Altares, Guillermo, "El problema de Kosovo es su excepcionalidad", El País, 4 May 2018.

ARENDT, Hannah, "La mentira en política. Reflexiones sobre los documentos del Pentágono”, Verdad y mentira en la política, Barcelona, Página Indómita, 2017.

Barkin, Samuel and Cronin, Bruce, "The State and the Nation: Changing Norms and the Rules of Sovereignty in International Relations", International Organization, vol. 48, no. 1, 1994.

Biersteker, Thomas J. and Weber, Cynthia, State Sovereignty as Social Construct, Cambridge University Press, 1996.

Carnicero, Carlos, "Kosovo: una china en el zapato de Rajoy”, Huffington Post, 17 May 2018.

CASSESE, Antonio, "Ex Iniuria Ius Oritur: Are We Moving Towards International Legitimation of Forcible Humanitarian Countermeasures in the World Community?", European Journal of International Law, vol. 10, 1999.

CUnLIFFE, Philip, "Sovereignty and the Politics of Responsibility", in BICKERTON, Christopher J. et al., Politics without Sovereignty. A Critique of Contemporary International Relations, University College London Press, 2007.

Dal Ri Júnior, Arno and CARneSElla, Gustavo, "El reconocimiento de nuevos Estados como sujetos en la ciencia del derecho internacional a partir de la deflagración de la Segunda Guerra Mundial: abordajes doctrinarios de la Convención de Montevideo a la «Opinión Consultiva Kosovo» (1933-2010)”, Anuario Mexicano de Derecho Internacional, vol. 17, 2017.

Doli, Dren and Korenica, Fisnik, "What about Kosovo's Constitution: Is There Anything Special?”, Vienna Journal of International Constitutional Law, vol. 5, no. 1, 2011.

DŽIHIĆ, Vedran and Kramer, Helmut, "Kosovo After Independence. Is the EU's EULEX Mission Delivering on its Promises?”, International Policy 
Esta revista forma parte del acervo de la Biblioteca Jurídica Virtual del Instituto de Investigaciones Jurídicas de la UNAM

Analysis, Berlin, 2009, available at: https://library.fes.de/pdf-files/id/ipa/0 6571.pdf.

European Union Council, "Council Decision (CFSP) 2018/856 Amending Joint Action 2008/124/CFSP on the European Union Rule of Law Mission in Kosovo", available at: http: / /www.eulex-kosovo.eu/eul/reposito ry/docs/CouncilDecision-203336.pdf.

Eurostat, "Enlargement Countries - Labour Market Statistics", available at: https: / / ec.europa.eu/eurostat/statistics-explained/pdfscache/32178.pdf.

FERnÁNDEZ IbÁÑEZ, Miguel, "Kosovo, el Estado medio fallido que se siente traicionado”, Público, 17 February 2018.

GREIÇEVCI, Labinot, "EU Actor in International Affairs: The Case of EULEX Mission in Kosovo", Perspectives on European Politics and Society, vol. 12, no. 3, 2011.

Gutiérrez, Cesáreo and Bermejo, Romualdo, "De la Opinión Consultiva de la Corte Internacional de Justicia, de 22 de julio de 2010, sobre Kosovo" (Documento de trabajo, 35/2010), Real Instituto Elcano, 10 November 2010 .

HolzGrefe, J. L. and KeOHAne, Robert E. (eds.), Humanitarian Intervention Ethical, Legal, and Political Dilemmas, Cambridge University Press, 2003.

Jara Gómez, Ana M., Kosovo en el laberinto. Estado, derecho y derechos, Granada, Comares, 2019.

JARA GÓMEZ, Ana M., "Soberanía, guerras justas y responsabilidad de proteger”, Criterio Jurídico, vol. 16, no. 2, 2016, available at: https: / / revistas. javerianacali.edu.co/index.php/criteriojuridico/article/view/2127.

JimÉnEZ PIERnAS, Carlos, "Los principios de soberanía e integridad territorial y de autodeterminación de los pueblos en la Opinión Consultiva sobre Kosovo: una oportunidad perdida”, Revista Española de Derecho Internacional, vol. 63, 2011.

KelSEn, Hans, Pure Theory of Law, 2nd. ed., trans. of Max Knight, New Jersey, The Lawbook Exchange, 1967-2005.

KRESS, Christian, When Is Military Intervention Morally Justified?, Norderstedt, Grin Verlag für Akademische Texte, 2005.

LÓPEZ-JURADO, Carmen, "Kosovo ante la Corte Internacional de Justicia: la Opinión Consultiva de 22 de julio de 2010", Revista Electrónica de Estudios Internacionales, vol. 21, 2011.

ManZAno, Cristina, “¿A quién le importa Kosovo?”, Huffington Post, 10 May 2013. 
Mayall, James, "Humanitarian Intervention Revisited”, in BUCKLEY, Mary and Cummings, Sally N. (eds.), Kosovo. Perceptions of War and its Aftermath, Great Britain, Bookends Ltd., 2001.

Molina, Ignacio, "Kosovo como problema, Europa como solución y la incidencia del Informe Marty", Aquiescencia, 21 December 2010, available at: https: / / aquiescencia.net/2010/12/21/kosovo-como-problema-europa-comosolucion-y-la-incidencia-del-informe-marty-por-ignacio-molina/.

Molina, Ignacio, “Kosovo como problema. Europa, la solución”, El País, 15 December 2010.

Molina, Ignacio, "Kosovo y Cataluña: distintos y distantes", Real Instituto Elcano, 6 December 2012.

Murphy, Sean D., Humanitarian Intervention:The United Nations in an Evolving World Order, Philadelphia, University of Pennsylvania Press, 1996.

Revista Española de Defensa, no. 137-138, July-August 1999.

RICHTER, Solveig, "Promoting Rule of Law without State-Building: Can EULEX Square the Circle in Kosovo?", in Asseburg, Muriel and Kempin, Ronja, The EU as a Strategic Actor in the Realm of Security and Defense? A Systematic Assessment of ESDP Missions and Operations, Stiftung Wissenshaft und Politik, Research Paper 2009/RP 14, December 2009.

RizZI, Andrea, “Kosovo: una década de independencia, una odisea inacabada hacia el Estado de derecho”, El País, 16 February 2018.

RODLEY, Nigel S. and ÇALI, Başak, "Kosovo Revisited: Humanitarian Intervention on the Fault Lines of International Law", Human Rights Law Review, vol. 7, no. 2, 2007.

SAHITI, Naim, "The Xhemail Kada School. From Kosovo with Sadness", La Opinión de Granada, 8 April 2009.

Secretary General of the United Nations, "Statement on the New Period of Engagement on Kosovo", 1 August 2007, available at: http: / /www. un.org/sg/statements/?nid=2692.

SeCurity Council (United Nations), "Comprehensive Proposal for the Kosovo Status Settlement”, S/2007/168/Add.1, 26 March 2007, available at: https: / / www.securitycouncilreport.org/atf/cf/\%7B65BFCF9B-6D274E9C-8CD3-CF6E4FF96FF9\%7D / Kosovo\%20S2007\%20168.Add1.pdf.

SECURITy Council (United Nations), "Letter Dated 10 November 2005 from the President of the Security Council Addressed to the SecretaryGeneral", S/2005/709, available at: https://reliefweb.int/report/serbia/ko sovo-letter-dated-10-nov-president-security-council-addressed-secretary-general. 
Esta revista forma parte del acervo de la Biblioteca Jurídica Virtual del Instituto de Investigaciones Jurídicas de la UNAM

Security Council (United Nations), "Report of the European Union/ United States/Russian Federation Troika on Kosovo", S/2007/723, 10 December 2007, available at: http: / / www.securitycouncilreport.org/atf/cf/ \%7B65BFCF9B-6D27-4E9C-8CD3-CF6E4FF96FF9\%7D/Kosovo\%20S200 7\%20723.pdf.

SeCURity Council (United Nations), "Report of the Special Envoy of the Secretary-General on Kosovo's Future Status”, S/2007/168, 26 March 2007, available at: https: / / reliefweb.int/sites/reliefweb.int/files/resources / 4B F3EA59396D0797852572AA007977D0-Full_Report.pdf.

SeCurity Council (United Nations), "Statement by the President of the Security Council”, S/PRST / 2005/51, 24 October 2005, available at: http: //www.un.org/en/ga/search/view_doc.asp?symbol=S/PRST/2005/51.

Simma, Bruno, "NATO, the UN and the Use of Force: Legal Aspects", European Journal of International Law, vol. 10, 1999.

Spernbauer, Martina, "EULEX Kosovo:The Difficult Deployment and Challenging Implementation of the Most Comprehensive Civilian EU Operation to Date", German Law Journal, vol. 11, no. 8, 2010.

TAIBO, Carlos, "Incomodidades kosovares", El Correo, 3 January 2008.

TAibo, Carlos, "Kosovo y las esencias”, Público, 16 February 2008.

TAibo, Carlos, "Los horizontes para Kosovo", El País, 15 April 1998.

TAibo, Carlos, “¿Y por qué no un Kosovo independiente?”, El País, 18 April 1999.

Talmon, Stefan, "The Constitutive versus the Declaratory Theory of Recognition: Tertium Non Datur?”, British Yearbook of International Law, vol. 75, no. 1, 2004.

TANSEY, Oisín, "Does Democracy Need Sovereignty?", Review of International Studies, vol. 37, no. 4, 2011.

TAnsey, Oisín, "Kosovo: Independence and Tutelage", Journal of Democracy, vol. 20, no. 2, 2009.

“The Revelations of WikiLeaks”, El País, 12 April 2010.

VAQUER I FANÉs, Jordi, “Kosovo avanza, pese a las dificultades”, Opinión CIDOB, no. 95, 17 December 2010.

VIDAl Folch, Xavier, “Cataluña no es Kosovo”, El País, 13 August 2017.

VIDMAR, Jure, "Explaining the Legal Effects of Recognition”, International and Comparative Law Quarterly, vol. 61, no. 2, 2012.

VIDMAR, Jure, "International Legal Responses to Kosovo's Declaration of Independence”, Vanderbilt Journal of Transnational Law, no. 42, 2009. 
Esta revista forma parte del acervo de la Biblioteca Jurídica Virtual del Instituto de Investigaciones Jurídicas de la UNAM

VIDMAR, Jure, "Remedial Secession in International Law: Theory and (Lack of) Practice”, St. Antony's International Review, vol. 6, no. 1, 2010.

WeT, Erika de, "The Governance of Kosovo: Security Council Resolution 1244 and the Establishment and Functioning of Eulex", The American Journal of International Law, vol. 103, no. 1, 2009.

WheELER, Nicholas J. and Bellamy, Alex J., "Humanitarian Intervention in World Politics”, in BAYLIS, John and SMITH, Steven (eds.), The Globalization of World Politics: An Introduction to International Relations, Oxford, Oxford University Press, 2008. 